\title{
3. Bibliography
}

Ackerknecht, Erwin H. (1942a) 'Problems of primitive medicine', Bulletin of the History of Medicine, 11: 503-521.

Ackerknecht, Erwin H. (1942b) 'Primitive medicine and culture pattern', Bulletin of the History of Medicine, 12: 545-574.

Ackerknecht, Erwin H. (1955) A short history of medicine (New York).

Adams, Francis (1849) Genuine works of Hippocrates; translated from the Greek, (London).

Allbutt, T. Clifford (1924) 'Letter of congratulation [to Sudhoff]', in Charles Singer and Henry E. Sigerist (eds) (1924) Essays in the history of medicine presented to Karl Sudhoff on the occasion of his seventieth birthday November 25th 1923 (London and Zurich).

Arcieri, John P. (1945) The circulation of the blood; and Andrea Cesalpino of Arezzo (New York).

Arundel, Thomas H. (1841) Catalogue of manuscripts in the British Museum (London).

Aselli, Gaspare (1627) De lactibus .... (Milan).

Bayon, H. P. (1941) 'Paracelsus: personality, doctrines and his alleged influence in the reform of medicine', Proceedings of the Royal Society of Medicine, 35: 69-76.

Berengario da Carpi, Jacopo (1522) Isagoge breves prelucide ac uberime in anatomiam humani corporis (Bologna).

Bevan, Edwyn R. and Singer, Charles, (eds) (1927) The legacy of Israel (Oxford).

Bickel, Marcel H. (ed.) (2008) Henry E. Sigerist: Vier ausgewählte Briefwechsel mit Medizinhistorikern der Schweiz (Bern).

Browne, Edward G. (1921) Arabian medicine (Cambridge).

Brunschwig, Hieronymus (1512) Liber de arte distillandi de compositis (Strassburg).

Capparoni, Pietro (1923) Magistri salernitani nondum cogniti (London).

Castiglioni, Arturo (1927) Storia della medicina (Milan).

Clapham, J. H. and Power, E. E. (eds) (1941-1989), Cambridge economic history, 9 vols (Cambridge).

Clarke, Edwin (1961) 'Charles Joseph Singer', Journal of the History of Medicine and Allied Sciences, 16: 411-419.

Constantinus Africanus (1560) Medicinae tam simplices .... (Basel).

Cope, Zachary (1960) 'Charles Joseph Singer (1876-1960)', Bulletin of the History of Medicine, 24: 471-473.

Cushing, Harvey and Streeter, Edward C. (eds) (1925) Giovanni Battista Canano, Girolamo da Carpi: Musculorum humani corporis picturata dissectio (Florence).

Dannemann, Friedrich (1898), Grundriss einer Geschichte der Naturwissenschaften, 2 vols (Leipzig).

Dannemann, Friedrich (1924), Ueber den Parallelismus in der Entwicklung der Naturwissenschaften und der Heilkunde, in Charles Singer and Henry E. Sigerist (eds) (1924), Essays in the history of medicine presented to Karl Sudhoff on the occasion of his seventieth birthday November 25th 1923 (London and Zurich) 349-368. 


\section{Bibliography}

Diels, Hermann (1912) Die handschriftliche Ueberlieferung des Galenschen Commentars zum Prorrheticum des Hippokrates (Berlin).

Dobell, Cecil Clifford (1932) Antonie van Leeuwenhoek and his "little animals", (London).

Drabkin, Israel (ed.) (1950), Aurelianus, Caelius: on acute diseases and on chronic diseases (Chicago).

Dryander, Johannes (1536), Anatomia capitis humani .... (Marburg).

Edelstein, Emma J. and Edelstein, Ludwig (1945) Asclepius; a collection and interpretation of the testimonies (Baltimore).

Emmart, Emily W. (1940) The Badianus Manuscript. An Aztec herbal of 1552 (Baltimore).

Etzioni, Mordecai (1945) 'The Hebrew-Aramaic Element in Vesalius' Tabulae anatomicae sex', Bulletin of the History of Medicine, 18: 413-424.

Flexner, Simon and Flexner, James T. (1941) William Henry Welch and the heroic age of American medicine, (New York).

Garrison, Fielding H. (1913) An Introduction to the History of Medicine (Philadelphia and London).

Garrison, Fielding H. (1924) 'The newer epidemiology', in Charles Singer and Henry E. Sigerist (eds) (1924) Essays in the history of medicine presented to Karl Sudhoff on the occasion of his seventieth birthday November 25th 1923 (London and Zurich) 255-268.

Giacosa, Piero (1898) Magistri salernitani nondum editi .... (Turin).

Green, Robert Montraville ([1951]), A translation of Galen's Hygiene: (De sanitate tuenda) with an introduction by Henry E. Sigerist (Springfield, Ill., Charles C. Thomas).

Green, Robert, and Licht, Sidney (1953) Selected Works of Galen, Translated by R. M. Green for S. Licht (New Haven).

Goldschmidt, Richard B. (1956) Portraits from memory. Recollections of a zoologist (Seattle).

Guthrie, Douglas (1945) A history of medicine (London).

Haeser, Heinrich (1881) Lehrbuch der Geschichte der Medizin, 2 vols, 3rd ed. (Jena).

Haggis, A. W. (1941) 'Fundamental errors in the early history of cinchona', Bulletin of the History of Medicine, 10: 417-459.

Hall, A. Rupert (1960) 'Charles Joseph Singer (1876-1960)', Isis, 51: 558-560.

Homo, Léon (1951) Rome Impériale et l' urbanisme dans l'antiquité (Paris).

Howald, Ernst and Sigerist, Henry E. (1927) Pseudo-Apulei herbarius (Leipzig and Berlin).

Hübotter, Franz, 3000 Jahre Medizin, Berlin, 1920.

Hume, Edgar E. (1942) Ornithologists of the United States Army Medical Corps (Baltimore).

Ivins, W. M. (1943) 'A propos of the Fabrica of Vesalius', Bulletin of the History of Medicine, 14: 576-593.

Jilla, Cyrus (1991) 'Charles Singer: his life, aims and achievements in the history of medicine', BSc Dissertation (London -Wellcome Institute for the History of Medicine).

Klebs, Arnold C., 'The Practica of Gianmatteo Ferrari da Gradi', in Charles Singer and Henry E. Sigerist (eds), Essays in the history of medicine presented to Karl Sudh- 


\section{Bibliography}

off on the occasion of his seventieth birthday November 25th 1923, London and Zurich, 1924, 211-236.

Koebert, Hermann (1888) De Pseudo-Apulei Herbarum Medicaminibus (Bayreuth).

Kristeller, Paul Oskar (1945) 'The School of Salerno', Bulletin of the History of Medicine, 17: $138-194$.

Kühn, Herbert (1922) Die Malerei der Eiszeit (München).

Laignel-Lavastine, P. M. Maxime (ed) (1936-1949) Histoire générale de la médecine, de la pharmacie, de l'art dentaire et de l'art vétérinaire. 3 vols (Paris).

Leake, Chauncey D. (1952) The Old Egyptian medical papyri (Lawrence, KS).

Liechtenhan, Eduard (1917) Sprachliche Bemerkungen zu Marcellus Empiricus (Basel).

Lind, L. R. and Asling, C. W. (eds) (1949) The Epitome of Andreas Vesalius (New York).

Livingston, R.W. (ed) (1921) The legacy of Greece (Oxford).

Lockwood, Dean P. (1951) Ugo Benzi; Medieval philosopher and physician (Chicago).

Lowe, Elias A. (1914) The Beneventan Script. A history of the South Italian minuscule (Oxford).

Malpighi, Marcello (1661) De pulmonibus observationes anatomicae (Bologna).

Manget, Jean-Jacques (1685) Bibliotheca anatomica (Geneva).

McKie, Douglas (1935) Antoine Lavoisier: the father of modern chemistry (London).

Meyer-Steinegg, Theodor and Sudhoff, Karl (1921) Geschichte der Medizin im Ueberblick mit Abbildungen (Jena).

Miller, Genevieve (ed.) (1946) William Beaumont's formative years (New York).

Miller, Genevieve (ed.) (1983) Letters of Edward Jenner and other documents concerning the early history of vaccination (Baltimore).

Mullett, Charles F. (1946) Public Baths and Health in England, 16th-18th Century. Supplement No. 5 Bulletin of the History of Medicine, 1-85.

Neuburger, Max (1906/1911) Geschichte der Medizin. 2 vols (Stuttgart).

Neuburger, Max and Pagel, Julius L. (eds) (1902-1905) Handbuch der Geschichte der Medizin, 3 vols (Jena).

Norden, F. (1921) Vom Altertum zur Gegenwart (Leipzig and Berlin).

Olmsted, James M.D. (1946) Charles-Eduard Brown-Séquard, a nineteenth century neurologist and endocrinologist (Baltimore).

Pagel, Walter (1935) 'Religious motives in the medical biology of the XVIIth century', Bulletin of the History of Medicine, 3: 97-128, 213-231, 265-314.

Pliny, the Elder, Natural history, with an English translation by W. H. S. Jones, vol 6 (1951), vol 7 (1956), vol 8 (1963), Loeb Classical Library Series (London: Heinemann).

Pettenkofer, Max (1858) Ueber den Luftwechsel in Wohngebäuden (Munich).

Peyer, Bernhard (1950) Goethes Wirbeltheorie des Schädels (Zurich).

Robert, Ffrangcon (1954) Medical Terms: Their Origin and Construction (London).

Rolleston, Humphry (1924) 'The reception of Harvey's doctrine of the circulation of blood in England', in Charles Singer and Henry E. Sigerist (eds) (1924) Essays in the history of medicine presented to Karl Sudhoff on the occasion of his seventieth birthday November 25th 1923 (London and Zurich), 247-254.

Sanchez de Rivera y Moset, Daniel (1921) Siluetas de médicos y libros de antaño .... (Madrid). 


\section{Bibliography}

Sarton, George (1952-) A history of science (Cambridge, MA).

Scott, Walter (1885) Hermetica: the ancient Greek and Latin writings .... (Boston).

Sigerist, Henry E. (1920) Die "Cirurgia Eliodori”, Archiv für Geschichte der Medizin, 12: $1-9$.

Sigerist, Henry E. (1921) 'Die "Lecciones Heliodori”", Archiv für Geschichte der Medizin, 13: 145-156.

Sigerist, Henry E. (1923a) Studien und Texte zur frühmittelalterlichen Rezeptliteratur (Leipzig).

Sigerist, Henry E. (ed.) (1923b) Ambroise Paré, die Behandlung der Schusswunden (Leipzig).

Sigerist, Henry E. (1923c) 'Eine deutsche Uebersetzung der Kethamschen Gynäkologie', Archiv für Geschichte der Medizin, 14: 169-178.

Sigerist, Henry E. (ed.) (1923d) The Book of Cirurgia by Hieronimus Brunschwig (Milan).

Sigerist, Henry E. (1923e) Albrecht von Hallers Briefe an Johannes Gesner 1728-1777 (Berlin).

Sigerist, Henry E. (1924) 'Die Geburt der abendländischen Medizin', in Charles Singer and Henry E. Sigerist (eds) (1924) Essays in the history of medicine presented to Karl Sudhoff on the occasion of his seventieth birthday November 25 th 1923 (London and Zurich), 185-205.

Sigerist, Henry E. (1933) Great doctors English translation (New York).

Sigerist, Henry E. (1934a) American medicine English Translation (New York).

Sigerist, Henry E. (1934b) 'The medical literature of the Early Middle Ages. A program and a report of a summer of research in Italy', Bulletin of the History of Medicine, 2: $26-50$.

Sigerist, Henry E. (1934c) 'On Hippocrates', Bulletin of the History of Medicine, 2: 190-214.

Sigerist, Henry E. (1934d) 'A summer of research in European libraries', Bulletin of the History of Medicine, 2: 559-610.

Sigerist, Henry E. (1936) 'The history of medicine and the history of science. An open letter to George Sarton', Bulletin of the History of Medicine, 4: 1-13.

Sigerist, Henry E. (1937a) Fielding H. Garrison Memorial Number. Bulletin of the History of Medicine, 5: 299-403.

Sigerist, Henry E. (1937b) Socialized medicine in the Soviet Union (New York).

Sigerist, Henry E. (1938) 'Report of the activities of the Institute of the History of Medicine of the Johns Hopkins University (1937-1938)', Bulletin of the History of Medicine, 6: 858-881.

Sigerist, Henry E. (1939) 'Yugoslavia and the XIth International Congress of the History of Medicine', Bulletin of the History of Medicine, 7: 93-147.

Sigerist, Henry E. (1940a) 'A physician's impression of South Africa', Bulletin of the History of Medicine, 8: 22-27.

Sigerist, Henry E. et al. (1940b)' Congratulatory epistle to Arnold C. Klebs', Bulletin of the History of Medicine (Arnold C. Klebs Number), 8: 319-328.

Sigerist, Henry E. (1940c) 18 articles in the New York Newspaper PM.

Sigerist, Henry E. (1941a) Medicine and human welfare (New Haven). 


\section{Bibliography}

Sigerist, Henry E. (1941b) 'Paracelsus in the light of four hundred years', in New York Academy of Medicine (ed.) The march of medicine (New York), 28-51.

Sigerist, Henry E. (ed.) (1941c) Four treatises of Theophrastus von Hohenheim called Paracelsus (Baltimore).

Sigerist, Henry E. (ed.) (1941d) The value of health to a city. Two lectures delivered in 1873 by Max von Pettenkofer, translated by H. E. Sigerist (Baltimore).

Sigerist, Henry E. (1942) 'The Sphere of Life and Death in Early Medieval Manuscripts', Bulletin of the History of Medicine, 11: 292-303.

Sigerist, Henry E. (1943a) Civilization and disease. (Ithaca, NY).

Sigerist, Henry E. (ed.) (1943b) Maurice Arthus' philosophy of scientific investigation (Baltimore).

Sigerist, Henry E. (1946) The university at the crossroads. Addresses and essays (New York).

Sigerist, Henry E. (1947) Medicine and health in the Soviet Union (New York).

Sigerist, Henry E. (1951) A history of medicine, vol. I (New York).

Sigerist, Henry E. (1952) 'Living under the shadow',. Atlantic Monthly 189: 25-30.

Sigerist, Henry E. (1953a) 'Johannes Hartlieb's gynaecological collection and the Johns Hopkins Manuscript', in E. Ashworth Underwood (ed.) (1953) Science, medicine and history. Essays on the evolution of scientific thought and medical practice, written in honour of Charles Singer 2 vols (London), vol 1, 231-246.

Sigerist, Henry E. (1953b) 'Erinnerungen an Karl Sudhoff', Archiv für Geschichte der Medizin, 37: 97-103.

Sigerist, Henry E. (1955) 'Review of Antonio Benivieni De abditis nunnullis ac mirandis morborum et sanationum causis' in Centaurus 4: 175-176.

Sigerist, Henry E. (1956a) Landmarks in the history of hygiene (London).

Sigerist, Henry E. (1956b) 'Erinnerungen an meine Leipziger Tätigkeit', Wissenschaftliche Zeitschrift der Karl-Marx-Universität Leipzig, Mathematisch-Naturwissenschaftliche Reihe, 5: 17-21.

Sigerist, Henry E. (1956c) 'Review of E.H.Ackerknecht $A$ short history of medicine' in Bulletin of the History of Medicine, 30: 278-279.

Sigerist, Henry E. (1958) 'The Latin medical literature in the Early Middle Ages', Journal of the History of Medicine and Allied Sciences, 13: 127-146.

Sigerist, Henry E (1961) A history of medicine Vol. II (New York).

Singer, Charles (1915) 'Allegorical representation of the Synagogue in a twelfth century illuminated MS. of Hildegard von Bingen' Jewish Quarterly Review, 5: 267-288.

Singer, Charles (1916-17) 'A review of the medical literature of the Dark Ages', Proceedings of the Royal Society of Medicine, Section History of Medicine, 10: 107-160.

Singer, Charles (1918-19) 'The Lorica of Gildas the Briton (? 547). A magico-medical text containing an anatomical vocabulary. Proceedings of the Royal Society of Medicine, 12: 124-144.

Singer, Charles (1921a) 'Review of Opera hactenus inedita Rogeri Baconi, Fasc. V, Secretum Secretorum ...., ed. by R. Steele', in Nature, 107: 771-772.

Singer, Charles (1921b) 'Biology', in R. W. Livingstone (ed.) (1921) The legacy of Greece (Oxford), 163-200. 


\section{Bibliography}

Singer, Charles (1921c) 'Medicine' in R. W. Livingstone (ed.) (1921) The legacy of Greece (Oxford), 201-248.

Singer, Charles (1921d) 'Greek biology and its relation to the rise of modern biology', in Charles Singer (ed.) (1921) Studies in the history and method of science, vol. 2 (Oxford: Clarendon Press), 1-101.

Singer, Charles (1923a) 'Ancient medicine', in F. S. Marvin (ed.) (1923) Science and civilization (London), 43-71.

Singer, Charles (1923b) 'The Dark Ages and the dawn', in F. S. Marvin (ed.) (1923) Science and civilization (London), 112-160.

Singer, Charles (1923c) [chapter on] 'Science', in C. Baily (ed.) (1923) The Legacy of Rome (Oxford), 265-324.

Singer Charles (1923d) 'Review of L. Thorndike, A history of magic and experimental science' in Observer 13 May, 5.

Singer, Charles (1923e) 'Herbals' Edinburgh Review, 237: 95-112.

Singer, Charles (ed.) (1924a) The Fasciculus Medicinae of Johannes de Ketham, Alemanus, with an introduction by Karl Sudhoff, translated by C. Singer. (Milan).

Singer, Charles (1924b) 'Jenner and vaccination', article on Jenner's Enquiry (facsimile), Times Literary Supplement, 20 Nov.

Singer, Charles (1924c) 'The Father of Medicine. Review of Hippocrates, vols i and ii by W. H. S. Jones; and Hippocrates and his successors by R. O. Moon, Times Literary Supplement, 3 April, 197-198.

Singer, Charles (1924d) 'The master of those that know. Review of Aristotle by W. D. Ross', British Medical Journal, 757-758.

Singer, Charles (1924e) 'Science in the Middle Ages. Review of Studies in the history of Mediaeval science by C. H. Haskins', Times Literary Supplement, 4 Dec., 813.

Singer, Charles (ed.) (1925a) The Fasciculo di Medicina Venice 1493 (With translation of Anathomia by Mondino da Luzzi) (Florence).

Singer, Charles (ed.) (1925b) The earliest printed literature on syphilis being ten tractates from the Years 1495-1498, Adapted from Karl Sudhoff (Florence).

Singer, Charles (1925c) The evolution of anatomy (London).

Singer, Charles (1925d) 'Historical relations of religion and science', in Joseph Needham (ed.) Science religion and reality (London), 85-148.

Singer, Charles (1927) 'The herbal in antiquity and its transmission to Later Ages', Journal of Hellenic Studies, 47: 1-52.

Singer, Charles (1928a) From magic to science. Essays on the scientific twilight. (London).

Singer, Charles (1928b) A short history of medicine (Oxford).

Singer, Charles (1928c) Religion and science considered in their historical relations (London).

Singer, Charles (1931) A short history of biology (Oxford).

Singer, Charles (1937a) 'German universities', The New Outlook, 12: 16-18.

Singer, Charles, (1937b) The Christian approach to Jews, with a foreword by the Rt. Rev. the Lord Bishop of Chichester; and a preface by the Rev. H. W. Fox (London).

Singer, Charles (1939) 'The legacy of Germany', Spectator, 1031-1032.

Singer, Charles (1941) A short history of science to the nineteenth century (Oxford). 


\section{Bibliography}

Singer, Charles (1942a) 'A great country doctor. Francis Adams of Banchory 1796-1861', Bulletin of the History of Medicine, 12: 1-17.

Singer, Charles (Anceps) (1942b) 'Christianity, science, and the religion of humanity', Political Quarterly, 13: 280-293 and 414-425.

Singer, Charles (1943) The Christian failure (London).

Singer, Charles (1945a) 'An early use of the word 'America', Times Literary Supplement, 14 July, 336.

Singer, Charles (1945b) 'Some Vesalian problems', Bulletin of the History of Medicine, 17: 425-438.

Singer, Charles (1945c) 'Beginnings of academic practical anatomy'. Historical essay in the reissue of L. Choulant, History and bibliography of anatomic illustration", trans. and annotated by M. Frank (New York), 21A-21R.

Singer, Charles (1946a) 'Review of the Circulation of the Blood and Andrea Cesalpino, by J.P. Arcieri', Bulletin of the History of Medicine, 19: 122.

Singer, Charles (1946b) 'Cesalpino and the circulation', British Medical Journal, i: 436.

Singer, Charles (1946c) 'Mme Hélène Metzger-Brühl', Bulletin of the History of Medicine, 19: 461-462.

Singer, Charles (1946d) 'Mme. H. Metzger-Brühl', Nature, 157: 472.

Singer, Charles (1948) The earliest chemical industry. An essay in the historical relations of economics and technology illustrated from the alum trade (London [?])

Singer, Charles (1949) Articles in The Oxford Classical Dictionary (Oxford).

Singer, Charles (1950) A history of biology, Revised edition (New York).

Singer, Charles (1951a) 'Review of $A$ history of medicine, vol. I, by H. E. Sigerist', British Medical Journal, ii: 587-588.

Singer, Charles (1951b) 'Review of A history of medicine, vol. I, by H. E. Sigerist', Bulletin of the History of Medicine, 15: 91-93.

Singer, Charles (1951c) 'An early parallel to the Hippocratic Oath', Gesnerus, 8: 177-180.

Singer, Charles (1951d) New worlds and old (London).

Singer, Charles (1952a) Vesalius on the human brain (London).

Singer, Charles (1952b) 'A MS. translation of the Arabic version of Galen's "De anatomicis administrationibus", Journal of the History of Medicine and Allied Sciences, 7: $85-86$.

Singer, Charles (1952c) 'Leonardo da Vinci', British Medical Journal, ii: 804-805.

Singer, Charles (1952d) 'Ancient Egyptian Medicine. Review of The old Egyptian medical papyri by Chauncey D. Leake', British Medical Journal, ii: 1201.

Singer, Charles (1952e) 'Galen's elementary course on bones', Proceedings of the Royal Society of Medicine, Section on the History of Medicine, 45: 25-34.

Singer, Charles (1952f) 'Personal hygiene in Ancient Rome. Review of A translation of Galen's Hygiene by Robert Montraville Green', British Medical Journal, i: 1404.

Singer, Charles (1954a) 'Some early goldwork', Endeavour, 13: 86-93.

Singer, Charles (1954b) 'How medicine became anatomical', British Medical Journal, ii: 1499-1503.

Singer, Charles, (ed.) (1956a) Galen on Anatomical Procedures: de Anatomicis administrationibus / translation of the surviving books (London). 


\section{Bibliography}

Singer, Charles (1956b) 'Obituary George Sarton', Nature 178: 67.

Singer, Charles (1956c) 'Review of A short history of medicine by E.H.Ackerknecht', Nature 177: 909.

Singer, Charles (1959) A short history of scientific ideas (Oxford).

Singer, Charles and Grattan, John H. G. (1952) Anglo-Saxon magic and medicine (London).

Singer, Charles, Holmyard, Eric and Hall, A. R. (eds) (1954-1958) History of technology (Oxford).

Singer, Charles and Long, Esmond R. (1954) De abditis nonnullis ac mirandis morborum et sanationum Causis (Springfield, IL).

Singer, Charles and Rabin, Chaim (1946) A Prelude to Modern Science. Being a Discussion of the History, Sources and Circumstances of the 'Tabulae Anatomicae Sex' of Vesalius (Cambridge).

Singer, Charles and Sigerist, Henry E. (eds) (1924) Essays in the history of medicine presented to Karl Sudhoff on the occasion of his seventieth birthday November 25th 1923 (London/Zurich).

Singer, Charles and Singer, Dorothea (1919) 'On a miniature, ascribed to Mantegna, of an operation by Cosmas and Damian', in Contributions to medical and biological research, dedicated to Sir William Osler, vol. 1 (New York), 166-176.

Singer Charles and Singer, Dorothea (1924) 'The origin of the medical school of Salerno', in Charles Singer and Henry E. Sigerist (eds) (1924) Essays in the history of medicine presented to Karl Sudhoff on the occasion of his seventieth birthday November 25th 1923 (London and Zurich), 121-138.

Singer, Dorothea W. (1924) Selections from the works of Ambroise Paré (London).

Sloane, Hans (1707-1725) A voyage to the islands, Madera, Barbados, Nieves, S. Christophers and Jamaica (London).

Smith, Frederick and Bullock, Fred (1919-1933) Early history of veterinary literature (London).

Spencer, Walter G. (1924) 'The 'Epitome' of Vesalius on vellum in the British Museum Library', in Charles Singer and Henry E. Sigerist (eds) (1924) Essays in the history of medicine presented to Karl Sudhoff on the occasion of his seventieth birthday November 25th 1923 (London and Zurich), 237-244.

Steele, Robert (1921) 'Roger Bacon', in Charles Singer (ed.) (1921) Studies in the history and method of science, vol. 2 (Oxford), 121-150.

Stelluti, Francesco (1630) Persio/tradotto in verso (Roma).

Streeter, Edward C. and Singer, Charles (1924) 'Fifteenth century miniatures of extramural dissections', in Charles Singer and Henry E. Sigerist (eds) (1924) Essays in the history of medicine presented to Karl Sudhoff on the occasion of his seventieth birthday November 25th 1923 (London and Zurich), 207-210.

Sudhoff, Karl (1912a) Graphische und typographische Erstlinge der Syphilisliteratur aus den Jahren 1495 und 1496, Alte Meister der Medizin und Naturkunde 4, (Munich).

Sudhoff, Karl (1912b) Aus der Frühgeschichte der Syphilis, Studien zur Geschichte der Medizin, Heft 9, (Leipzig).

Sudhoff, Karl (1922) Kurzes Handbuch der Geschichte der Medizin (Berlin). 


\section{Bibliography}

Sudhoff, Karl (ed.) (1923) Der Fasciculus medicinae des Johannes de Ketham, Alemannus (Milan).

Sudhoff, Karl (1924) Zehn Syphilis-Drucke aus den Jahren 1495-1498 (Milan).

Taylor, F. Sherwood (1938) Galileo and the freedom of thought (London).

Temkin, Owsei (1945) Falling sickness, a history of epilepsy (Baltimore).

Thierfelder, Johann G. (1943) Additamenta ad Henrici Haeseri bibliothecam epidemiographicam (Meissen).

Tietsch, F. L. (1939) 'Self-portrait of Fielding H. Garrison. Autobiographical excerpts compiled from his letters', Bulletin of the History of Medicine, 7: 365-373.

Thorndike, Lynn (1923-1958) History of magic and experimental science during the first thirteen centuries of our era (New York).

Thorndike, Lynn (1924) 'Disputed dates, civilization and climate, and traces of magic in the scientific treatises ascribed to Theophrastus', in Charles Singer and Henry E. Sigerist (eds) (1924) Essays in the history of medicine presented to Karl Sudhoff on the occasion of his seventieth birthday November 25th 1923 (London and Zurich), 73-86.

Townend, B. R. (1944) 'The Story of the Toothworm', Bulletin of the History of Medicine, 15: 37-58.

Underwood, E. Ashworth (ed.) (1953) Science, medicine and history. Essays on the evolution of scientific thought and medical practice, written in honour of Charles Singer, 2 vols (London).

Underwood, E. Ashworth (1960) 'Charles Singer (1876-1960)', Medical History, 4: 353-358.

Vesalius, Andreas (1552) De humani corporis fabrica (Leyden).

Wake, William Charles (1966) 'Who was Hippocrates?' The Listener, 19 Dec.

Walzer, Richard (1944) Galen on medical experience (New York).

Wedel, Theodore O. (1920) The Medieval attitude towards astrology (New Haven).

Wehrli, Gustav Adolf (1920) 'Die inneren Körperorgane in den Kinderzeichnungen mit einigen ethnographischen Parallelen', Mitteilungen der Geographisch-Ethnographischen Gesellschaft Zürich, 35-51.

Wissowa, Georg (ed.) (1893-) Paulys Realencyclopädie der klassischen Altertumswissenschaft (Stuttgart).

Withington, Edward T. (1924) 'Roger Bacon, On the Errors of Physicians', in Charles Singer and Henry E. Sigerist (eds) (1924) Essays in the history of medicine presented to Karl Sudhoff on the occasion of his seventieth birthday November 25th 1923 (London and Zurich) 139-157.

Zimmermann, Ernst H. (1916) Vorkarolingische Miniaturen (Berlin). 